\title{
Local Tradition and Harmony among Religious Adherents: the Dominant Culture of Hindu-Muslim Relation in Jembrana Bali
}

\author{
Saihu Saihu ${ }^{\text {* }}$ \\ 1 Institut PTIQ Jakarta, Indonesia; e-mail: madesaihu@ptiq.ac.id \\ * Correspondence
}

Received: 2020-03-21; Accepted: 2020-05-14; Published: 2020-05-29

\begin{abstract}
This study discusses the harmony of Hindu-Muslim's local traditions in Jembrana, western Bali. This anthropology study employs Bruner's dominant cultural theory approach to see the practice of harmony in local communities. This study focuses on several local Hindu-Muslim traditions in Jembrana, which reflect harmony among religious communities, namely the tradition of ngejot, makepung, male, and rebana (tambourine). The ethnographic study confirms the importance of respect for the dominant culture carried out by the Muslim minority when implementing their religious traditions. Although the customs of male and rebana, for instance, are Islamic traditions, Balinese Muslims adapted to Balinese customs as the dominant culture. They understood their positions to maintain and respect the dominant Balinese culture performed by the majority of Hindus in Jembrana. Balinese Hindus tried to show an excellent response to the Muslims by involving them in the local Balinese tradition even with the adaptation of their rituals. It is a wealth of local tradition that shows religious harmony portrait in Indonesia.
\end{abstract}

Keywords: dominant culture; harmony; Hindu; local tradition; Muslim.

Abstrak: Bali merupakan salah satu daerah yang dihuni oleh ragam komunitas agama. Kajian ini membahas kerukunan umat Hindu dan Muslim di Jembrana Bali dilihat dari sudut pandang budaya dominan dalam tradisi lokal yang melibatkan kedua pemeluk agama tersebut. Tradisi ngejot, makepung, male, dan rebana merupakan tradisi lokal yang menunjukkan kerukunan Hindu-Muslim tersebut. Melalui pendekatan teori kebudayaan dominan, studi etnografi ini menegaskan pentingnya penghormatan terhadap kebudayaan dominan yang dilakukan oleh minoritas Muslim ketika melaksanakan tradisi agamanya. Meski tradisi male dan rebana misalnya, bersumber dari tradisi Islam, tetapi pengaruh kebudayaan dominan mampu mendorong terjadinya penyesuaian dengan adat Bali sehingga kerukunan lebih mudah terjaga. Di sini kaum Muslim memahami posisinya untuk menjaga dan menghormati kebudayaan dominan yang dianut oleh mayoritas umat Hindu di Jembrana Bali. Hal yang sama dilakukan oleh umat Hindu yang berusaha menunjukkan respons baik terhadap kaum Muslim dengan turut melibatkan mereka dalam tradisi ngejot bahkan dalam kadar tertentu ditunjukkan dengan penyesuaian agar tidak bertentangan dengan keyakinan Muslim. Sebuah kekayaan tradisi lokal yang menunjukkan potret kerukunan antar umat beragama di Indonesia.

Kata Kunci: Hindu; Kebudayaan Dominan; Kerukunan; Muslim; Tradisi Lokal. 


\section{Introduction}

In Indonesia, religion has become an increasingly important identity marker in the 21st century. The shared history and practice of people are tested, shaped, and renegotiated in similarities and differences. It has created a variety of accepted situations, either harmony or discrimination, depending on the relationship and the context in which they act (Hauser-Schäublin \& Harnish, 2014, p. 1). Self and other people identification in a society based on religion produce new forms, namely majority, and minority. Even people live together without previously delineating the boundary markers among them.

Bali is one area that shows various negotiations of religious identity, either similarities and differences or majority and minority. In Bali, well-known as the God Island, Hindus and Muslims live in differences with adherents of other religions. Amid the threat of radicalism and terrorism in Indonesia and Southeast Asia, Hindu-Muslim in Bali is relatively undisturbed. Even though the bomb attacks occurred there in 2002 and 2005, the two religious communities with various ethnic backgrounds (Balinese, Sasak, Javanese, Buginese, Sundanese, and others) remained unprovoked. Both Hindus and Muslims help each other in supporting the continuity of their respective religious traditions. Scholars say there is a kind of local cultural power in "managing diversity from within" so that harmony can be created. An effort to manage diversity, one of which is based on respect for the dominant local culture that makes religion and cultural systems as a source of values (Sila, 2017, p. 119).

This study focuses on several local Hindu-Muslim traditions in Jembrana, western Bali, which reflect harmony among religious communities, namely the culture of ngejot, makepung, male, and rebana (tambourine). Jembrana has stood out the history of Hindu-Muslim relations compared to other regions such as Denpasar, Klungkung, Badung, Gianyar, Buleleng, Tabanan, Karangasem, and Bangli. Because of its position bordering the coastline East Java along Bali Strait, Jembrana has a long history of contact with Muslim immigrants from Makassar Bugis with Balinese Hindus since the 17th century (Nordholt, 1996). Explaining Hindu-Muslim relations at Jembrana Bali means revealing diverse experiences on various issues such as ethnicity, religious identity, tolerance, and harmony. Therefore, studying religious relations in Bali provides an opportunity to explore how the majority with their dominant culture controls power over others in dominating spiritual life or promoting goodwill, harmony, and better social experience.

Besides, some Muslim base areas in Bali did not practice various local traditions such as ngejot, makepung, male, and rebana as Hindu-Muslim in Jembrana did. They practiced ngejot tradition during religious and customary ceremonies, such as feast, births, or wedding days, by exchanging food. Makepung tradition is a buffalo race involving Hindu-Muslim in Jembrana. Male culture is an egg decoration to welcome the Prophet's birthday or birth ceremony. Meanwhile, rebana/tambourine tradition is a Muslim tradition performed in the nuances of traditional Balinese music and clothing.

This anthropology study employs Bruner's dominant cultural theory approach to see the practice of harmony in local communities directly. This theory sees that inter-ethnic harmony and religious adherents can be created when all ethnicities and religions respect the predominant cultural system. Minority groups choose a "succumbing" attitude for the sake of creating harmony among community groups (E.M. Bruner, 1974; Edward M. Bruner, 1961). The ethnographic research is conducted around January-June 2019, along with a series of interviews with Hindu and Islamic religious leaders in Jembrana (Spradley, 2016).

The study of various local traditions that reflect the harmony of Hindu-Muslims in Jembrana is essential in order to show the influential role of local religion and culture in managing differences between the two communities. While getting a better security situation after the bomb attacks in 2002 and 2005, they are trying to show harmony through various local traditions. A tradition is a cooperation form as support of citizenship bonds in the form of participation in associations to succeed in local religious and cultural ceremonies (Varshney, 2012).

Amid popularity studies on Bali in various social-humanities perspectives such as mythology, art, ritual, social organization, politics, law to child care, scholars also have studied sociologicalanthropological studies of Hindu-Muslim relations in Bali. Generally, they focused on historical aspects, majority-minority issues, regional autonomy, and tensions after Bali bombings (Budiwanti, 
1995; Hauser-Schäublin, 2004, 2007; Sastrodiwiryo, 1995; Vickers, 1987; Wikan, 1990). Some scholars had also recently explained the role of local traditions in maintaining Hindu-Muslim harmony in Bali (Aliffiati, 2014; Arif, 2019; Armini, 2017; Basyir, 2016; Fahham, 2018; Jannah, 2017; Karim, 2016; Kartini, 2017; Lestawi, 2012; Maknun, 2018; Pageh, 2018; Rusmayani \& Gunawan, 2018; Sabarudin \& Arif, 2019; Suwindia, 2012). However, only a few of the research, as mentioned above, explain the Hindu-Muslim relations in Bali from the perspective of the dominant culture as one of the supporting factors of harmony among ethnic and religious groups. This study reveals the importance of the cultural perspective of respected dominant and adorns various Hindu-Muslim traditions in Jembrana Bali. This study describes another view of local customs and Hindu-Muslim harmony in an area that is dominated by cultural expressions that are guarded and respected by all adherents of religions.

\section{The Dominant Culture and Relations among Ethnicities and Religions in Indonesia}

In anthropological studies, the dominant cultural theory perspective (dominant culture) is used in explaining the diversity of ethnic groups and religions. Bruner (1915-2016), a famous American anthropologist, explained the theory in the context of the study of plurality and belief in Indonesia. According to him, dominant culture is a substantive model that reflects the reality of inter-tribal relationships in the context of local power structures. The nature relationship among local tribes and the natural connection between each of these tribes with the local power structure produce inter-tribal relations (E.M. Bruner, 1974). In addition to the elements of social demography and the existence of social forces in various tribes, the essential ingredients in determining inter-ethnic relations are the dominance of local tribal culture, the methods usually practiced by migrant tribes in dealing with local tribes, and the use of their respective cultures and articulations. The migrants try to adjust to the localdominant culture so that harmony among tribes can be realized.

Bruner gave an example of how the position of Sundanese people in Bandung was able to apply Sundanese cultural patterns predominantly to all people in Bandung so that other tribes adapted to the dominant culture. It is different from Medan. There is not a single dominant ethnicity in terms of social and cultural demographics. Each tribe maintains its culture and ethnicity, living in groups among tribes and religions so as to strengthen inter-ethnic competition in the power structure of Medan City. Social life in Bandung is characterized by regularity because non-Sundanese migrants adapt themselves to Sundanese culture and tend to become Sundanese. In contrast, in Medan, each tribe creates order in their internal environment. In the public sphere, each tribe competes and bargains power in the form of conflict or cooperation among tribal groups in winning the competition (E.M. Bruner, 1974).

Suparlan, one of the Indonesian Scholars, applied dominant culture theory in reading the case of community adaptation strategies in Bandung, Sambas, and Ambon. Through comparison of the three cases, Suparlan revealed the different adaptation strategies among Javanese in Bandung, Madurese in Sambas Central Kalimantan, and BBM (Buton, Bugis, Makassar) people in Ambon Maluku. Javanese from the lower classes in Bandung regard Sundanese culture as the dominant culture. They adopted the Sundanese way of behaving. Harmonious relations between migrants and Sundanese as hosts can be maintained.

In contrast, the Madurese in Sambas and BBM in Ambon imposed their roles and principles so that they dominated the indigenous population. As a result, there occurred conflicts between indigenous people and migrants. Therefore, the dominant culture as a specific framework with rules and norms must be followed by migrants and outsiders. However, challenges to dominant culture can, of course, vary in society (Suparlan, 2014).

Thus, the dominant culture theory is critical in analyzing the relationship between ethnicities and religions in Indonesia. It can explain how harmony can maintain ethnic and religious relations by giving appreciation to the dominant culture where they live together. In addition to the conflict cases in Sambas and Ambon, several instances of violence in the name of religion in several other regions in Indonesia such as Poso, Manislor, Cikeusik, Tolikara, Sampang, Tanjungbalai and the issue of blasphemy by Ahok, showed a lack of respect for the dominant culture among tribal members and religious adherents (Vltchek, 2012). 
In the case of Ahok or Basuki Tjahaja Purnama, for example, initially emerged from Ahok's statement as a Chinese Christian who was considered blasphemous to the Qur'an and Islamic teachings ahead of Jakarta Governor's election in 2017. His position as a religious adherent and descendant of minority ethnic groups in Jakarta was considered not able to maintain and respect the dominant culture prevailing in the society. His interaction with the majority of Muslims is not going well. It then led to various fatwas and responses even triggered a reaction to the Islamic Defendant Action 212 demonstration organized by GNPF-MUI (Gerakan Nasional Pembela Fatwa - Majlis Ulama Indonesia/ National Movement to Defend Fatwa - Indonesian Ulema Council). Finally, Ahok apologized, although he was convicted by the court and given a sentence of two and a half years in prison (Hatherell \& Welsh, 2017; Miichi, 2019).

However, in contrast to several cases of horizontal conflict among members of tribes and religions, based on dominant culture theory, several regions in Indonesia can maintain harmony among ethnic and religious relations well. The 2017 Setara Institute survey related to the harmony index in several cities in Indonesia shows that ten cities have the highest harmony index, namely Manado, Pematangsiantar, Salatiga, Singkawang, Tual, Binjai, Kotamobagu, Palu, Tebing Tinggi and Surakarta (Setara Insitute, 2017). ). People in these cities can maintain and apply the value of harmony and tolerance in the diversity situation where they live. Sri Eko also found that several other regions such as Buneng Hamlet, Boro Village in Blitar, and East Java are places that have the competency of intercultural communication and respect local wisdom to maintain tolerance among ethnic and religious groups peacefully (Eko \& Putranto, 2019). These patters also occurred in several other regions in Indonesia. One of them is Hindu-Muslim relations in Jembrana Bali, which shows respect for the dominant culture prevailing in the community to maintain harmony between Hindus and Muslims, as will be examined in this article.

\section{Socio-Cultural Context of Jembrana: a Research Location}

Jembrana is one of the districts in the west of Bali Province. The coastline of East Java is seen passing along the strait of Bali. The total population is around 307,804 people. This area consists of five districts, namely Negara, Mendaya, Jembrana, Melaya, and Pekutatan. As a tourist area, Jembrana has quite many studios (seka or a place to develop art). Those are more than 1,300 studios. Most of them are located in Negara District. Several types of Jembrana distinctive art were developed at the art studio, including Jegog (gamelan musical instruments from bamboo), Joged Bungbung (dances), Kendang Mebarung (musical instruments from the skin) and Bungbung Gebyog (dances accompanied by alu instruments for pounding rice) (Bappeda dan Penanaman Modal Pemerintah Kabupaten Jembarana, 2011; Sukerna \& Bandem, 2001).

The population majority of Jembrana is Hindu, with a total of about 224,583 people $(73 \%)$. Meanwhile, Muslims are approximately 75,580 people (24\%). The rest are Christians, Catholics, Buddhists, Confucianists, and religious believers. Therefore, temples in this area dominated the number of worship places with 290 units, whereas the number of mosques as worship places for Muslims is at the second with 197 units spread across several Muslim settlements (Pemerintah Kabupaten Jembrana, 2011). Muslims in the west of Bali may consist of local Balinese or come from East Java and other regions in Indonesia. However, for Balinese Hinduism, Islam has always been regarded as a foreign element along with them. In Jembrana, some Muslims use Malay in communication, although they also speak Bugis and Balinese. Some of them come from Malay descent of Kuala Trengganu and Makassar Bugis tribe, who had come to Jembrana since the 17th century (Ahmad Damanhuri, personal communication, March 7, 2019).

Jembrana has an industrial area dominated by certain ethnic and religious groups. Various industries are fish processing, wood and cafe illustrate how various economic factors influence the views of local communities regarding ethnic and religious differences there. It showed a particular role dominated by certain ethnic and religious groups. It described an ambiguous arena of social relations in the symbol of religious moralism that permeated Indonesian citizenship and Hindu-Muslim identity 
in Bali. In Jembrana, cultural adjustment, and political domination by local Balinese Hindus are challenged in intense competition in the workplace (Bagus, 2014).

Historically, Hindu and Islamic relations in Jembrana have long been characterized by cooperation and conflict, integration, and division, especially with East Java. The ties of Bali and East Java encompassed the entire history of the Balinese dynasty. East Java represents the origins of Hinduism and Islam and sustains a tension between closeness and openness. Bali, according to Nordholt, is an open fortress that shows how the dynamics and cultural space of religion within this fortress were formed mainly by religious stereotypes. Its stereotype reflects internal and interfaith differences (Nordholt, 2007).

Jembrana is close to the East Java area and invisible isolated from the traditional cultural and political center of Hindu Balinese. The traditional cultural and political center of the Hindu Balinese is located in Buleleng in the north of Bali. The various inland kingdoms and kingdoms in the southeastern region of Bali collectively refer to Buleleng (kungin or eastern areas) as a reflection of authentic and original Balinese ideas. In Jembrana, social contacts and historical experience are recognized but retold with different statements by various ethnic groups, religions, and caste groups (Nordholt, 1996).

This area is a gateway area that has a strategic position, especially for changes in political hegemony in Bali, who want to access Java and control Bali strait. As the fall of Majapahit, the Javanese Hindu kingdom, in the 16th century and the arrival of educated elites to Bali, they influenced religious and political matters in this area (Creese, 1991). These Hindu-Buddhist immigrants established their influence on the local Balinese that can be felt to this day. They have social and political control and contribute to the strengthening of Hindu-Buddhist religious beliefs and practices. It is understandable that Muslim preachers from the east of Java only touched a part of Bali. The approached Balinese rulers refused to convert to Islam (Vickers, 1987).

Some Muslim communities then developed along the north coast of Bali, a place where various interactions with Muslim traders occurred for several centuries (Hauser-Schäublin, 2004). Jembrana in west Bali, which become a gateway to Bali, represents the differences in ethnic communities between Hindus and Muslims for many centuries. Jembrana is the outermost post and a place of defense for some of the Balinese ruler's successors who controlled the area to maintain its territory in response to the Bugis/Bajo settlements along the west coast.

The Bugis moved from Sulawesi due to Dutch colonial attacks around the 17th century. The migrant community movement has the potential to deter local Balinese from easy targets launched between Java and Bali. The Bugis sailors established a hidden harbor called Loloan, twelve kilometers inland around the tide of the Ijo Gading river. They carried out piracy along the Bali Strait and fought against the Dutch in East Java. The Hindu Palace, Puri Agung Negara, was established next to the Loloan settlement and eventually became the capital. The relationship between the local rulers of Bali and the Bugis was full of danger. For three years at the beginning of the 19th century, Buginese forces controlled the area. Bugis became mercenaries for the rulers of Bali in the south. They became effective rulers in obtaining their rights at Jembrana at that time.

The dispute to control the Bali strait occurred between the Balinese Hindu ruler and Bugis Muslim population. However, arising conflicts are more political conflicts, not religion. It was always about cases of controlling over coastal trade and problems of access to East Java. This dispute was repeated when there was an expansion of Dutch colonial power over Bali. When the Dutch took control of Buleleng and Karangasem in 1849, they also forced to agree with Jembrana authorities. It was a strategy to conquer Bali and, in turn, rule East Java (Dharmayuda, 1995).

Based on this historical evidence of interfaith and ethnic competition, the first Muslims in Jembrana were mercenaries and fishermen from Bugis. Only then did Arabs, Malays, East Javanese, Madurese, and Sasak come in many phases as fishermen, teachers, refugees, and laborers. The residents of Jembarana were originally also local Balinese Hindu immigrants whose ancestors had initially isolated themselves and fled from around the royal house from elsewhere in Bali. These historical experiences show the various dynamics of claims to the territory during the resulting period from the 
collaboration and integration of local communities, as well as conflicts and divisions between Hindus and Muslims (Bagus, 2014).

In the recent past, the Hindu-Muslim community in Jembrana has tried to maintain harmony between the two religious communities in various ways. One of them is respecting the dominant culture in Bali, which adorns a variety of local traditions, as will be explained in this study.

\section{Local Traditions and Hindu-Muslim Relations in Jembrana}

As explained before, Hindu-Muslim in Jembrana has historically been marked by cooperation and conflict. However, over time, the collaboration between the two adherents has been continually strengthened. One of those cooperations is through the practice of local traditions. Local traditions are used as a socio-cultural mechanism in fostering brotherhood and solidarity among religious adherents (Abela, 2004; Butler, 2016; Suprapto, 2017). It is related to local wisdom as the dominant culture prevailing in Balinese society as a reference in behavior. The Balinese generally have several principles of local wisdom such as Nyame Selam / Balinese / Hindu (Muslim / Balinese / Hindu siblings), menyamabraya (consider others as their own siblings), metetulung (helping each other) either ngidih tulung (be asked) or mesuaka (not be asked), paras-poros (the tradition of borrowing), nandu, ngadas, mekadasang (working on rice fields or livestock), ngayah (a mutual cooperation) and others (Fahham, 2018; Suwindia, 2012). Those local wisdom are then manifested in various traditional practices that reflect harmony among ethnic and religious groups in Bali.

In Jembrana are important local traditions in strengthening Hindu-Muslim relations such as ngejot, makepung, male and rebana. These traditions are carried out by an appreciation of the dominant culture prevailing in Jembrana. Therefore, although several traditions have initially been part of the Islamic tradition, in practice, the dominant culture of Bali influenced this custom as a form of appreciation. Conversely, although some of these traditions are of Hindu origin, Muslims will also try to respect them by preserving them as a form of harmony.

\section{Ngejot Tradition, Local Food, and Harmony}

Ngejot is a sharing food tradition (jotan) between Hindus and Muslims during the marriage, birth, or religious ceremonies. Either Hindus or Muslims carries out this tradition if they want to carry out certain traditional or religious ceremonies. They will invite family and neighbors from other religions to send food as an expression of gratitude. Invited residents will also come with food supplies such as rice, sugar, coffee, and so on. For example, When Hindus carry out Galungan or Kuningan, they will send food to their fellow brothers and sisters from Muslims with halal food.

Conversely, Muslims will also send food to their Hindu brothers. Likewise, when Muslims fast during the month of Ramadan, one form of respect given by Hindus to Muslims is to do ngejot by providing breaking food such as diamonds, fruit, engkud ice (young coconut water) and so on. It is an intercultural communication between Hindus and Muslims that reflects harmony and local wisdom through food (Sumiati, 2017).

I Komang Arsana, Chairman of Parisada Hindu Dharma Indonesia and Chairman of FKUB Jembrana, justified sharing food tradition in ngejot. He said,

When I celebrate Galungan, Kuningan, or other celebrations, I always think of ngejot or sending

food to my Muslim brothers (menyama braya) as a form of sima krama dharma santhi (friendship).

Of course, the food I gave is not against Islamic law. Therefore, the positive impact of ngejot is

extraordinary in maintaining harmony and strengthening the sense of brotherhood among

fellow believers (I Komang Arsana, Personal Communication, April 7, 2019).

Ali Rahman, Head of Kelapa Balian Hamlet Environment, also acknowledged this statement. He stated that ngejot was a means of strengthening the brotherhood of fellow humans (ukhuwah insaniyah) and friendships of fellow citizens (ukhuwah wathaniyyah) (Ali Rahman, personal communication, April 7, 2019).

The statement shows that Hindu-Muslim harmony in Jembrana is reflected in the tradition of food dishes in ngejot that respects other religions. On Galungan, Hindus cut pigs, but they will provide halal 
food for Muslims because they appreciate the Islamic teachings that forbid these animals. Therefore, ngejot is as same as woni (eating together) of Catholic-Muslims in Manggarai East Nusa Tenggara. Food can be a symbol of the identity of a community in strengthening harmony among religious communities (Lon \& Widyawati, 2019).

In addition to ngejot tradition, in animal slaughter ceremonies are efforts to respect each other among Hindus and Muslims in Jembrana. The relatively close position of the domicile and place of worship of Hindus-Muslims encourages certain adjustments in certain rituals. Like Negara people whose mosque and temple positions are close together, the ritual of slaughtering animals is replaced with other animals so that they do not offend each other. When Hindus commemorate Galungan, they do not kill pigs in honor of Muslims. Conversely, when Muslims celebrate the Eid al-Adha, they do not slaughter cows but goats or buffaloes in honor of Hindus, who regard cows as purified animals.

According to I Made Kembang Hartawan, Deputy Regent of Jembrana, harmony among religious communities in Jembrana, as shown in the ngejot tradition, is inseparable from the maturity in religion and understanding of the value of diversity. Maturity and knowledge of ethnic and religious diversity in Bali are running quite well so that they are wiser and more tolerant of the common good. Hartawan (Personal Communication, April 7, 2019) also said: "There is no religion that teaches violence. I often help the construction of mosques, Islamic boarding schools, mushala, even though I am a Hindu, because, for me, heaven and hell are the things for God to arrange, what is important is that we do good to others." The same thing was conveyed by Putra (Personal Communication, April 1, 2019), who called it an adaptive (adaptation) and adoptive (adopting good value) culture. So that life between religious people in Jembrana can run in harmony and harmony (Putra, Personal Communication, April 1, 2019).

Historically, ngejot tradition is a Balinese Hindu tradition handed down from generation to generation. Firstly, this tradition is only held on Hindu holidays such as Galungan, Kuningan, and Nyepi. The food provided is usually in the form of cakes, fruits, urap, lawar, and pork. Later, the tradition was carried out by Muslims in Bali. Since the arrival of Muslim immigrants from Bugis, Java, Sasak, and other regions, they have then carried out the tradition also when welcoming Eid Fitri, Eid al-Adha or when holding religious ceremonies and other celebrations. There is cultural acculturation occurs in ngejot tradition carried out in different religious traditions.

Based on the perspective of dominant cultural theory, ngejot tradition shows how Muslims try to understand the dominance of Balinese culture in their daily lives. Therefore, as a form of tolerance for the diversity of religions and cultures in Bali, Muslims try to apply ngejot tradition in the religious ceremony. Ngejot tradition determines the relationship between Hindu-Muslim religions in the form of domination of local Hindu culture so that Muslims as migrants can have good relations with Hindus. The Muslims try to adapt to the dominant local culture in ngejot tradition so that harmony among religions in Jembrana Bali can be realized.

Therefore, although previous scholars emphasized the role of ngejot tradition in the context of interfaith harmony in Bali, the dominant cultural perspective was not found in their studies. It shows that ngejot culture is a Hindu-Muslim relationship marked by interfaith communication between hospitality in Islam and katwang asih in Hinduism (Basyir, 2018; Saihu \& Şahin, 2020). Besides, it also a form of Muslim awareness as a minority of immigrants in understanding the dominant culture in which they live. Therefore, it is mistaken to be considered part of 'da'wah event' (an Islamic propagation) by some scholars (Baharun, 2018). It is a view that emphasizes the unilaterally hidden interests of Islam that contradicts the local wisdom of ngejot as a harmony reinforcement between Hindu-Muslims.

\section{Makepung Tradition, Games and Harmony}

In addition to ngejot tradition, Hindu-Muslim in Jembrana Bali is also involved in Makepung tradition. It is a buffalo racing tradition of the Melaya region in Jembrana Bali in welcoming rice harvest, like the race of cattle in Madura. Makepung means chasing. There are two buffaloes (pepadu or racers) in one pair chasing each other in the muddy rice fields with the other pair to be a winner. The distance between the two pairs of buffalos is usually ten meters. There are hundreds of buffalo in each of these traditions. This tradition is generally held to compete for the trophy of the regent or governor to 
increase tourist visits. There are several arenas in Makepung tradition, such as Sanghyang Cerik, Delod Berawah, Mertasari, Awen, Tuwed, and others. Makepung is usually closed with buffalo clothing contests and makepung dances accompanied by jegog musical instruments (Arshiniwati, 2003).

This tradition was initially carried out by farmers to plow rice fields in cooperation during the growing season. They use two buffalo to pull the plow (lampit) ridden by a jockey or sais. The activity then developed into a game to compete with each other's buffalo strength. The jokey wears dress in ancient Balinese royal warriors style, namely a headband (destar), shawl and sling (seelempod or trousers on the waist tucked into a sword covered in poleng or black and white). However, since the 1960s, Makepung tradition is no longer carried out on the mud, but on roads around rice fields (dry fields). This change occurred along with the formation of the Makepung organization consisting of two groups named "Regu Ijo Gading Timur" with a red flag symbol and the group of "Regu Ijo Gading Barat" with a green flag symbol (Anggariyana et al., 2019; Hardianta et al., 2015).

When makepung is carried out on a dry field, the facilities also change. There is no lampit but rather small carts or carts filled with Balinese decorations and carvings. For the event, the jockeys use traditional clothing, namely wearing a batik shirt, long-sleeved shirt, sling, trousers, and shoes, but no longer slips the sword at the waist. According to Ida Bagus Idagosa, a Hindu community figure, every year Makepung is always routinely carried out in Jembrana when farmers finish harvesting between July-October. It is usually also followed by entertainment programs such as dangdut orchestra, bumbung dance, and cockfighting (Ida Bagus Indagosa, Personal Communication, April 9, 2019). According to Darma Putra, a Balinese community leader, Balinese Hindus strive to show hospitality and respect to all citizens in daily life, whether they are known each other or not, to maintain a harmonious and peaceful life (Ida Bagus Dharma Putra, Personal Communication, April 7, 2019).

In the context of Hindu-Muslim relations in Jembrana, Makepung has an essential role in maintaining harmony between the two religious communities in Jembrana. Not only Hindus, Muslims are also involved in the Makepung event. Both religious people consider it a form of gratitude for God's blessing and kindness. Sociologically-anthropologically, Makepung tradition shows social cohesiveness, increasing income, fostering togetherness, cooperation, and harmony among religious adherents. Although initially, it was a Balinese tradition to welcome rice harvest, Muslims also later involved in efforts to provide support to Makepung tradition as part of the dominant culture that must be respected to preserve local culture in Bali.

The game of Makepung differs significantly from that of cockfighting in Bali. According to Geertz, the custom of cockfighting represents various meanings related to the social structure of Balinese society, such as a shift in the hierarchy of ideal male status, caste, and social status represented in this game (Geertz, 1973). Cockfighting is prohibited, while makepung is encouraged. Therefore, viewing Makepung tradition in a sociological-anthropological manner is more related to the social ties of the community in fostering togetherness, especially between Hindu-Muslim communities in the dominant cultural frame.

\section{Male Tradition, Egg and Togetherness}

Male tradition also reflects Hindu-Muslim harmony relations. Although this tradition developed in the Muslim community in Jembrana, in practice, Hindus were also involved in its implementation. Male tradition is usually carried out in commemoration of the birth of the Prophet Muhammad. The term male refers to the decoration of boiled eggs without peeled skin that is strung together in particular shapes and then displayed on a banana tree in front of the mosque called Pajegan. The series of eggs was initially formed and decorated in colors to resemble temples, ships, bonsai trees, or camels. Male is usually then also used as a gift for the invitees and people who attended the event. This tradition was also later presented at the baby birth ceremony as a blessing and gratitude to God (Saihu, 2019).

Male tradition during the celebration of the birth of the Prophet usually begins with a village tour with colorful egg decorations in various forms. The public then paraded it by escorting a security officer dressed in Balinese custom called pager uyung. These security officers are not only from Muslims but 
also from Hindus called pecalang. Muslims went around while reading asrakal, a kind of Salawat and praise while beating tambourines and marawis.

After completing the village tour, all male ornaments were collected at the mosque. The eggs are then pierced by bamboo and plugged into a banana tree. It is called pajegan. From a distance, it looks like a banana tree bearing egg. After being displayed, the congregation recited Salawat $d i b a^{\prime}$ which tells the Prophet's life journey as an expression of love for him. The recitation of Salawat was ended by distributing pajegan eggs to Muslim worshipers and Hindus. People usually scramble and jostle to get the egg. It is considered a blessing because it has been recited by Muslim religious leaders (Karim, 2016).

According to KH. Ahmad Muzakki, Chairperson of Jembrana MUI, male tradition contains the kindness value in order to create harmony among religions. It contains at least three meanings, namely aesthetic, ethical, and social purposes. Aesthetically, male shows a nuanced culture of art with the reading of Salawat and hymns of the Prophet. Ethically, its procession wandering around wearing traditional Balinese attire indicates that Muslims are asking permission from the majority of Hindus to carry out the Muslim holy day. Therefore, Muslims form male not only with a distinctive form of Islamic symbol but also a kind of temple. Besides, pecalang from the Hindu community also participated in securing around the village. It shows that although Muslims practice male tradition, the nuances of Balinese customs as the dominant culture are still valued for the sake of harmony. Ida Bagus Arnawa conveyed a similar statement and said:

It is not only Hindu who assist Muslims in their religious ceremonies, like male, but Muslim also help and participate in preparing equipment and facilities in Hindus ceremonies. Although we have a different faith, we build excellent communication and cooperation in social relations. The important thing is to live in harmony and help each other, because through a balance, of course, God will facilitate to achieve material welfare (Ida Bagus Putu Arnawa, Personal Communication, April 7, 2019).

The meaning of ethics is very closely related to the social sense in which the Hindu-Muslim community feels socially bound to respect each other's cultural and religious traditions. Therefore, during male ritual, Hindus maintain security and help in the distribution of male eggs during Muslim celebrations. The Muslims will do the same and involved in maintaining security during Hindu religious ceremonies, such as Nyepi, Kuningan, and Galungan (Ahmad Muzakki, Personal Communication, April 4, 2019). The effort to respect each religious celebration between the Hindu majority and the Muslim minority is a form of awareness in maintaining harmony within the dominant cultural frame in Jembrana Bali. The shape of male resembles a temple, the involvement of pecalang, traditional Balinese clothing and the presence of Hindus in obtaining male eggs show appreciation for the dominant culture by Muslims. It is a tradition based on mutual awareness to build a harmonious life in diversity. Hindu-Balinese people in Jembrana realize that despite their different religions, these differences do not become obstacles to living in harmony in creating a peaceful society.

\section{Rebana or Tambourine Tradition and Harmony in Art}

Another local tradition in Jembrana that shows the harmony of Hindu-Muslim relations in the dominant cultural frame is the tambourine tradition. It is commonly found in various Muslim communities in Indonesia. Usually, a tambourine musical instrument beats accompanied by the singing of Islamic poems using Arabic or Malay. But, its tradition in Jembrana Bali is a bit different. The tambourine players try to arrange songs using Balinese rhythms. Besides, some traditional Balinese musical instruments and traditional Balinese clothing are also used in combination with the veil. It is an art harmony performed when welcoming the Prophet's birthday, the holy month of Ramadan, circumcisions, and other religious ceremonies. It shows that the traditional tambourine has become a means of strengthening Hindu-Muslim harmony through the arts.

According to Ida Bagus Putu Arnawa, a Hindu religious leader in Jembrana, all Jembrana people know that this tambourine or burdah art is from Muslims, but to strengthen the kinship between Hindus and Muslims the tradition has a different nuance from the performance in other regions. In Bali, the players use the traditional Balinese musical instruments, wear conventional Balinese clothing and sing 
the song that depicts the Hindu-Muslim living harmony in Jembrana that was built since the 17th century (Ida Bagus Putu Arnawa, personal communication, April 7, 2019).

Besides, this tambourine art tradition involves both Muslims and Hindus as happened in the Air Kuning area. Hindus involvement shows their proper response to Muslims to respect them through the arts (Asmari, Personal Communication, April 9, 2019). Accompanied by songs in Arabic and Malay that contained harmony stories plus musical instruments and traditional Balinese clothing marked two religious communities were trying to create peace, especially in Jembrana. It shows that although tambourine tradition developed initially in the Muslim community, it has adapted to the dominant culture in which they live. Muslims try to modify to the dominance of Balinese customs practiced by Hindus; thus, the tambourine art is tailored to the dominant culture.

As a harmony symbol between Hindus and Muslims in Bali, the tambourine art even represented Bali province at Istiqlal Festival in Jakarta in 1995. Jembrana Regent at the time, Ida Bagus Indagosa, sent a tambourine performing art that performed by both Muslim and Hindu with traditional Balinese attire. The lyrics they brought were not only Salawat, but also the Balinese song. When the Hindus performed, they sang Salawat lyrics. Conversely, when Muslims performed, they sang Balinese song lyrics. This fact shows how a local art tradition can be used to knit differences in a colorful weave. Through tambourine performance art, they conveyed the message to Indonesian people about religious harmony in Bali as a valuable noble tradition in the Jembrana region (Ida Bagus Indagosa, Personal Communication, April 9, 2019).

Thus some local traditions as a mirror of harmony realization between religious communities in Jembrana Bali, namely Hindus and Muslims. Those traditions are ngejot, makepung, male, and tambourine traditions. Both Hindus and Muslims practice all these traditions in Jembrana as preservation to the local custom of Bali.

Theologically, in the beliefs of Hindus, some of these local traditions are manifestations of the teachings of tri hita karana (devotions, pawongan, and palemahan - relationship with God, humans, and nature). All the three affirmed the view that humanity is a brother or tatwam asi as known among Balinese by the expression "you are me, and I am you" (I Komang Arsana, Personal Communication, April 7, 2019). Islamic teachings have similar beliefs that encourage good relations with God, humans, and nature, hablumminallah, habluminannas, and hablumminal'alam (Ahmad Muzakki, Personal Communication, April 4, 2019).

Based on the perspective of dominant culture theory, as Bruner stated at the beginning, the local tradition has become a substantive model that reflects the reality of inter-ethnic relations and religion in the context of local power structures. It is manifested power in the form of a dominant culture that is highly respected by all religious adherents in Jembrana. Therefore, the built harmony is basically very much determined by a minority of immigrants that respect the dominant culture, so they are involved in maintaining the local power structure (E.M. Bruner, 1974). The Muslim community as a minority tries to adapt to the dominant local culture prevailing in Jembrana so the harmony among tribes can be realized.

\section{Conclusions}

This study shows that local traditions can contribute to maintaining harmony among religious communities through respect for the dominant local culture. The Hindu-Muslim community in Jembrana practices it in the tradition of ngejot, makepung, male, and tambourine. Although these traditions originate from specific religions, both religious communities have tried to be involved in them. Both are equally aware of the importance of their involvement in the local tradition. However, this study also shows the importance of respecting the dominant culture practiced by Muslim minorities when implementing their religious rituals. Although male and tambourine traditions, for example, are Islamic traditions, the influence of dominant culture can encourage adaptation to Balinese customs so that harmony is more easily maintained. Here, Muslims understand their position to support and respect the dominant culture of the majority of Hindus in Jembrana Bali. Without respect for the prevailing local culture, relations among ethnicities and religions may lead to a competition 
which can lead to conflict as has happened in some areas in Indonesia. Therefore, the dominant culture is one of the crucial keys to understanding local traditions in the context of ethnic and religious differences. It is a perspective that places the diversity of local traditions as a symbol of communication among cultures and religions in Indonesia.

\section{References}

Abela, A. M. (2004). Solidarity and religion in the European Union: A comparative sociological perspective. The Value (s) of a Constitution for Europe, 71-101.

Aliffiati, A. (2014). Interaksi Sosial Antarumat Beragama di Perumahan Bumi Dalung Permai Desa Dalung, Kuta Utara, Badung. Jurnal Kajian Bali (Journal of Bali Studies), 4(1).

Anggariyana, I. K., Sunu, I. G. K. A., \& Sanjaya, D. B. (2019). Tradisi Makepung dalam Pemertahanan Budaya Lokal di Kabupaten Jembrana. Jurnal Pendidikan Kewarganegaraan Undiksha, 7(2), 44-54.

Arif, M. (2019). A Mosque in a Thousand Temple Island: Local Wisdom of Pegayaman Muslim Village in Preserving Harmony in Bali. Wawasan: Jurnal Ilmiah Agama Dan Sosial Budaya, 4(1), 16-30. https://doi.org/10.15575/jw.v4i1.4809

Armini, G. A. (2017). Toleransi Masyarakat Multi Etnis dan Multi Agama dalam Organisasi Subak di Bali. Patanjala : Jurnal Penelitian Sejarah Dan Budaya, 5(1), 38. https://doi.org/10.30959/patanjala.v5i1.152

Arshiniwati, N. M. (2003). Tari Makepung: Sebuah Refleksi Tradisi Budaya Masyarakat Jembrana. Mudra, 12(2), 17.

Bagus, M. I. (2014). Ethnicity, Religion and the Economic Imperative: Some Case Studies from the Fringes of West Bali. In B. Hauser-Schaublin \& D. D. Harnish (Eds.), Between Harmony and Discrimination: Negotiating Religious Identities within Majority-Minority Relationship in Bali and Lombok. Brill.

Bappeda dan Penanaman Modal Pemerintah Kabupaten Jembarana. (2011). Profil Kabupaten Jembrana tahun 2011. Bappeda dan Penanaman Modal Pemerintah Kabupaten Jembarana.

Basyir, K. (2016). Membangun Kerukunan Antarumat Beragama berbasis Budaya Lokal Menyama Braya di Denpasar Bali. Religió: Jurnal Studi Agama-Agama, 6(2), 186-206. https://doi.org/10.15642/religio.v6i2.603

Bruner, E.M. (1974). The Expression of Ethnicity in Indonesia. In A. Cohen (Ed.), Urban Ethnicity. Tavistock.

Bruner, Edward M. (1961). Urbanization and Ethnic Identity in North Sumatra. American Anthropologist, 63(3), 508521. https://doi.org/10.1525/aa.1961.63.3.02a00040

Budiwanti, E. (1995). The Crescent Behind The Thousand Holy Temples. An Ethnographic Study of the Minority Muslims of Pegayaman North Bali. Gadjah Mada University Press.

Butler, D. (2016). Living prayer: Its contributions for the world's ecosystems and interreligious harmony. Jurnal Kajian Bali (Journal of Bali Studies), 6(1), 81-118.

Creese, H. (1991). Balinese babad as historical sources; A reinterpretation of the fall of Gèlgèl. Bijdragen Tot de Taal, Land-En VolkenkundelJournal of the Humanities and Social Sciences of Southeast Asia, 147(2-3), 236-260.

Dharmayuda, I. M. S. (1995). Kebudayaan Bali: Pra Hindu, Masa Hindu dan Pasca Hindu. Kayumas Agung.

Eko, B. S., \& Putranto, H. (2019). The Role of Intercultural Competence and Local Wisdom in Building Intercultural and Inter-religious Tolerance. Journal of Intercultural Communication Research, 48(4), 341-369. https://doi.org/10.1080/17475759.2019.1639535

Fahham, A. M. (2018). Dinamika Hubungan Antarumat Beragama: Pola Hubungan Muslim dan Hindu di Bali. Jurnal Aspirasi, 9(1), 65-84.

Geertz, C. (1973). Deep Play: Notes on the Balinese Cockfight. In C. Geertz (Ed.), The Interpretation of Cultures, Selected Essays by Clifford Geertz. Basic Books, Inc., Publishers.

Hardianta, I. K. S., Sudiatmaka, K., Si, M., Sanjaya, D. B., \& Si, M. (2015). Identifikasi Nilai-nilai Pendidikan Karakter Pada Tradisi Makepung Sebagai Sumber Belajar PPKn Di SMP N 4 Mendoyo (studi kasus di Desa Pakraman Delod Berawah Kecamatan Mendoyo, Kabupaten Jembrana, Bali). Jurnal Pendidikan Kewarganegaraan Undiksha, 3(1).

Hatherell, M., \& Welsh, A. (2017). Rebel with a Cause: Ahok and Charismatic Leadership in Indonesia. Asian Studies Review, 41(2), 174-190. https://doi.org/10.1080/10357823.2017.1293006

Hauser-Schäublin, B. (2004). Bali Aga and Islam: Ethnicity, Ritual Practice, and Old-Balinese as an Anthropological Construct. Indonesia, 77, 27-55.

Hauser-Schäublin, B. (2007). Rivalling Rituals, Challenged Identities: Accusations Of Ritual Mistakes As An Expression Of Power Struggles In Bali (Indonesia). In When Rituals go Wrong: Mistakes, Failure, and the Dynamics of Ritual (pp. 245-271). BRILL. https://doi.org/10.1163/ej.9789004158115.i-377.87

Hauser-Schäublin, B., \& Harnish, D. D. (2014). Between harmony and discrimination: Negotiating religious identities within majority-minority relationships in Bali and Lombok. Brill. 
Jannah, S. R. (2017). Kegalauan Identitas: Dilema Hubungan Muslimin dan Hindu di Bali. Ulumuna, 16(2), $443-464$. https://doi.org/10.20414/ujis.v16i2.186

Karim, M. A. (2016). Toleransi UmaT Beragama di desa loloan, Jembrana, Bali (ditinjau dari Perspektif sejarah). Analisis: Jurnal Studi Keislaman, 16(1), 1-32.

Kartini, I. (2017). Dinamika Kehidupan Minoritas Muslim di Bali. Masyarakat Indonesia, 37(2), 115-145.

Lestawi, I. N. (2012). Pola Interaksi Komunitas Hindu-Islam: Studi Kasus Kerukunan Antarumat Beragama di Dusun Batu Gambir Desa Pakraman Julah Tejakula Buleleng.

Lon, Y. S., \& Widyawati, F. (2019). Food and Local Social Harmony: Pork, Communal Dining, and MuslimChristian Relations in Flores, Indonesia. Studia Islamika, 26(3), 445-474.

Maknun, M. L. (2018). Harmoni Hindu-Muslim Berbasis Tradisi Lisan Sejarah Desa Saren Budakeling Karangasem Bali. FIKRAH, 6(2), 341. https://doi.org/10.21043/fikrah.v6i2.4005

Miichi, K. (2019). Urban Sufi and politics in contemporary Indonesia: the role of dhikr associations in the anti'Ahok' rallies. South East Asia Research, 27(3), 225-237. https://doi.org/10.1080/0967828X.2019.1667110

Nordholt, H. S. (1996). The Spell of Power: A History of Balinese Politics 1650-1940. KITLV Press.

Nordholt, H. S. (2007). Bali: An Open Fortress, 1995-2005: Regional Autonomy, Electoral Democracy and Entrenched Identities. NUS Press.

Pageh, I. M. (2018). Kearifan Sistem Religi Lokal dalam Mengintegrasikan Umat Hindu-Islam di Bali. Jurnal Sejarah Citra Lekha, 3(2), 88. https://doi.org/10.14710/jscl.v3i2.19411

Pemerintah Kabupaten Jembrana. (2011). Profil Kabupaten Jembrana tahun 2011. Pemerintah Kabupaten Jembrana.

Rusmayani, R., \& Gunawan, A. H. (2018). Hubungan Mayoritas Hindu Bali terhadap Minoritas Muslim (Studi Toleransi Puri Pemecutan Terhadap Komunitas Minoritas Muslim di Kampung Bugis Serangan, DenpasarBali). Ngabari: Jurnal Studi Islam Dan Sosial, 11(1), 16-36.

Sabarudin, \& Arif, M. (2019). Kerukunan Hidup antar Umat Beragama berbasis Kearifan Lokal di Kampung Loloan, Jembrana, Bali. Jurnal Sosiologi Reflektif, 14(1), 1. https://doi.org/10.14421/jsr.v14i1.1722

Saihu, S. (2019). Pendidikan Karakter Berbasis Kearifan Lokal (Studi di Jembrana Bali). Edukasi Islami: Jurnal Pendidikan Islam, 8(01), 69-90.

Sastrodiwiryo, S. (1995). Beberapa Faktor Penting dalam Hubungan Hindu-Islam di Bali: Sebuah Tinjauan Historis. In I. B. Mantra, U. Wiryatnaya, \& J. Couteau (Eds.), Bali di Persimpangan Jalan: Sebuah Bunga Rampai. Nusa Data Indo Budaya,.

Setara Insitute. (2017). Ringkasan Eksekutif Indeks Kota Toleran (IKT) Tahun 2017. Setara Institute.

Sila, M. A. (2017). Kerukunan Umat Beragama di Indonesia: Mengelola Keragaman dari Dalam. In I. A. Fauzi (Ed.), Kebebasan, Toleransi dan Terorisme: Riset dan Kebijakan Agama di Indonesia. Pusat Studi Agama dan Demokrasi, Yayasan Paramadina.

Spradley, J. P. (2016). The thnographic interview. Waveland Press.

Sukerna, I. N., \& Bandem, I. M. (2001). Gamelan Jegog: Ansambel bambu di Kabupaten Jembrana Bali. Universitas Gadjah Mada.

Sumiati, D. (2017). Intercultural Communication Based on Local Wisdom That Made the People of Bali Reject Sharia Tourism. Asian Journal of Media and Communication, 1(2), 137-146.

Suparlan, P. (2014). Kemajemukan, hipotesis kebudayaan dominan dan kesukubangsaan. Antropologi Indonesia.

Suprapto, S. (2017). Sasak Muslims And Interreligious Harmony: Ethnographic Study of the Perang Topat Festival in Lombok-Indonesia. Journal of Indonesian Islam, 11(1), 77-98.

Suwindia, I. G. (2012). Relasi Islam dan Hindu Perspektif Masyarakat Bali. Al-Ulum, 12(1), 53-76.

Varshney, A. (2012). Ethnic Conflict and Civic Life: Hindus and Muslims in India. Yale University Press.

Vickers, A. (1987). Hinduism and Islam in Indonesia: Bali and the Pasisir World. Indonesia, 44, 30. https://doi.org/10.2307/3351220

Vltchek, A. (2012). Indonesia, Archipelago of Fear. Pluto Press.

Wikan, U. (1990). Managing Turbulent Hearts: A Balinese Formula for Living. The University of Chicago Press.

(C) 2020 by the authors. It was submitted for possible open access publication under the terms and conditions of the Creative Commons Attribution (CC BY SA) license (https://creativecommons.org/licenses/by-sa/3.0/). 